\title{
Cervicofacial actinomycosis: important considerations on a mimicking disease
}

\author{
Actinomicosis cervicofacial: consideraciones importantes sobre una enfermedad imitadora \\ Lídia Mallmann 1,a, Renata Boff ${ }^{2, b}$, Valesca Koth ${ }^{2, \mathrm{~b}}$, Fernanda Salum ${ }^{2, \mathrm{c}}$, Maria Antonia Figueiredo ${ }^{2, \mathrm{c}}$, \\ Karen Cherubini ${ }^{2, \mathrm{c}}$
}

\section{RESUMEN}

La actinomicosis es una enfermedad infecciosa muy infrecuente de tipo crónico y supurativo que afecta al área cervicofacial e el tracto gastrointestinal. El presente trabajo tuvo como objetivo, revisar informaciones importantes en cuanto etiopatogenia, presentación clínica y tratamiento de la actinomicosis cervicofacial. Se puede clasificar de tres maneras a depender del sitio anatómico: cervicofacial (50\%), torácica (30\%) y abdominal (20\%). Presentamos una revisión de la literatura con foco en aspectos importantes de la actinomicosis cervicofacial. Aunque se le denomine micosis, la enfermedad es causada por bacterias grampositivas del género Actinomyces, siendo que $A$. israelli es el agente etiológico más frecuente, cuales son microorganismos comensales de la boca. Sin embargo, si la integridad de la mucosa es violada, ellos se tornan patogénicos. La actinomicosis es lentamente progresiva y frecuentemente imita otras condiciones clínicas como malignidades. El tratamiento consiste en terapia antibiótica y puede durar 12 meses en casos más graves. El conocimiento de los profesionales de salud acerca de esa enfermedad es fundamental para promover su prevención, diagnóstico precoz y tratamiento correcto.

PALABRAS CLAVE: actinomicosis cervicofacial, Actinomyces, infección

\section{SUMMARY}

Actinomycosis is a rare chronic suppurative infection that affects upper airways and the gastrointestinal tract. The aim of this work was to review important information regarding the etiopathogenesis, clinical features and treatment of cervicofacial actinomycosis. According to the anatomic site affected, it is classified into three clinical forms: cervicofacial $(50 \%)$, thoracic $(30 \%)$ and abdominal $(20 \%)$. We present here a literature review focusing on important aspects of cervicofacial actinomycosis. Despite the name comprising the term mycosis, the disease is caused by Gram-positive bacteria of the genus Actinomyces, mainly Actinomyces israelii, which are commensals of the oral microbiota. Nevertheless, when the integrity of the oral mucosa is compromised, they can become pathogenic. Actinomycosis evolves slowly and it often mimics other clinical conditions such as malignancies. Treatment consists in antibiotic therapy and can last up to 12 months in severe cases. Health care professionals' knowledge about the disease is crucial in a way to promote its prevention, early diagnosis and proper treatment.

KEY WORDS: cervicofacial actinomycosis; Actinomyces; infection.

Dental College, Pontifical Catholic University of Rio Grande do Sul, Porto Alegre, Brazil

Post-graduate Program, Dental College, Pontifical Catholic University of Rio Grande do Sul, Porto Alegre, Brazil

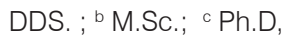




\section{INTRODUCTION}

Actinomycosis is a chronic suppurative infection that affects soft tissues $(1,2)$. Cope, in 1938, classified it into three different forms: cervicofacial $(50 \%)$, thoracic (30\%) and abdominal (20\%) (3). Actinomyces, the etiologic agents of the disease, are anaerobe/microaerophilic, Gram-positive, commensal bacteria, which are found in the oropharynx, gastrointestinal and urogenital tracts $(2,4)$. When these microorganisms reach subcutaneous tissues, especially in immunocompromised patients, they become pathogenic (1). The clinical presentation of this infection can be similar to that of tuberculosis and carcinoma, and therefore, actinomycosis can easily be mistaken for these diseases (3).

The diagnosis of cervicofacial actinomycosis is often delayed, probably because of its low prevalence and unawareness of health care professionals about the pitfalls involved in the diagnosis process. These professionals, especially physicians and dentists, must be aware of its potential occurrence as well as the therapeutic management of the disease. The aim of this work was to review, in the available scientific literature, important information regarding the etiopathogenesis, clinical features and treatment of cervicofacial actinomycosis.

\section{Etiopathogenesis}

Actinomycosis was described in 1848 by Langenback (5), and in 1878, Israel and Wolff (6) observed and described the sulfur granules in human disease, and defined the anaerobic nature of the microorganism (7). Originally, it was considered of fungal etiology (mycos), in view of the slow growth and filamentous appearance of Actinomyces. Afterwards, it was confirmed that these microorganisms were bacteria (5). Accordingly, the morphology of Actinomyces shows filaments much narrower than fungal hyphae (6) and bacillary forms as well, and reproduction occurs by binary fission instead of spore formation or budding $(5,6)$. Moreover, Actinomyces are killed by antibiotics, such as penicillin and erythromycin, but are not affected by antifungal drugs such as amphotericin B (5).

Actinomycosis is a rare infectious disease caused by various microorganisms of the genus Actinomyces, where Actinomyces israelli is the main etiologic agent in humans. However, A. naeslundii, A. viscosus, A. odontolyticus, A. meyeri, A. gerencseriae, A. pyogenes, A. georgiae, A. graevenitzii and A. neuii can also be involved in the pathogenesis of the disease $(3,7,8)$. Meanwhile, A. bovis is known to be the causative agent of actinomycosis in cattle but has never been isolated from humans (9).

Cervicofacial actinomycosis is the most prevalent form of the disease $(10,11)$. Actinomyces are part of the normal oral microbiota, where they are commensals of periodontal pockets, caries, dental plaque, calculus and gingival crevices (6). Nevertheless, they can become pathogenic by accessing the oral submucosa through an open door. Mucosal breaks play an important role in providing access to a microaerophilic environment favorable for infection. Therefore, factors such as complication of a maxillofacial trauma after surgical interventions and/or dental interventions in patients showing poor oral hygiene or caries can work as predisposing factors (figure 1) (1$4,12,14)$. Actinomycosis occurs almost exclusively by direct invasion, and rarely through hematogenous spread (6).

\section{Epidemiology}

Actinomycosis is an endogenous, non-contagious and rare infection (9), which does not have racial predisposition or involvement of geographic factors in its etiopathogenesis (14). However, immunosuppression predisposes to the disease (15). There is slight preference for males, with a male:female ratio of 2.4:1 (11). Among females, actinomycosis occurs more often between 11 and 30 years of age (11), whereas it is rare in the pediatric population (16). Lesions are more prevalent in the perimandibular region and seldom involve bone (17). When accessibility to penicillins was restricted, actinomycosis used to be fatal. During that time, mortality rates of up to $62 \%$ were reported (18).

\section{Clinical features}

Actinomycosis can occur in three different forms: acute, subacute or chronic (4). Usually the infection develops silently, showing a solid mass that slowly increases in size and forms many fistulas (figure 2), which are specific features of the chronic phase (19). The acute phase, however, is less frequent and shows fever, fatigue, malaise and floating edema, reminding an acute dental infection, where pain and trismus can also happen $(6,20)$. 


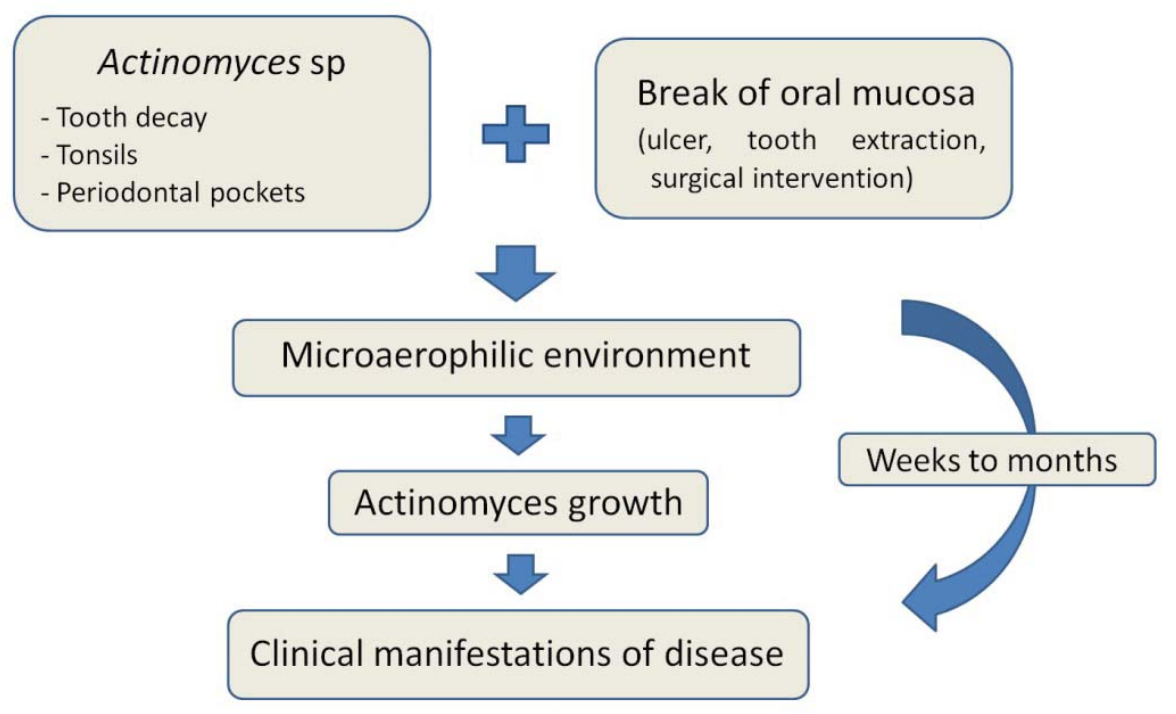

Figure 1. Etiopathogenesis of cervicofacial actinomycosis. Actinomyces are commensal microorganisms found in particular sites of oral cavity. Oral mucosa breaks act as an open door to a microenvironment favorable for infection, leading to disease onset.

In most cases, signs and symptoms of infection such as fever, sudden cervicofacial pain, erythema, and edema are absent (14). Initially, the lesions show woody consistency, mimicking neoplasm, but with time, fistulas appear in the region. The nodule then assumes the characteristic multifistulated aspect (2). There is spread in a contiguous way, regardless of tissue planes, and there is release of bacteria through the fistulas as sulfur granules (17). Regional lymphadenopathy is typically absent, also in more advanced stages (21). Cervicofacial actinomycosis can develop in surrounding tissues of any mandibular or maxilla sites. However, the mandibular region is the most frequent site of infection (6). Some cases can cause central nervous system (CNS) infection (2\%) (12) by means of direct extension via facial sinuses, orbits, ear canal and perineural (22), where it is possible for the trigeminal ganglion to be involved via the oval foramen (5).

\section{Diagnosis}

Careful evaluation of the clinical features can lead to a proper diagnosis, which has to consider the presence of sulfur granules, as well as the identification of organisms in the examined tissue and positive cultures (13). Diagnostic tests include the following: (a) histopathological examination, especially when it mimics other diseases such as primary or metastatic carcinoma (13); (b) imaging techniques such as computed tomography (CT) (14), ultrasonography (15) and nuclear magnetic resonance, which can help to define the mass characteristics and adjacent soft tissue involvement (14), where CT can show typical cervicofacial lesions appearing as poorly defined and infiltrative soft tissue masses, which can spread to contiguous spaces, along with the appearance of small necrotic areas (13); (c) cytological analysis of fine-needle aspirate, which is the method of choice for the diagnosis of actinomycosis, providing an easy, safe, fast and highly effective method, even though sometimes it might not provide a definitive diagnosis (14).

Cervicofacial actinomycosis can represent a diagnostic dilemma for clinicians because it can mimic other infectious diseases such as tuberculosis (scrofula), abscesses, cysts and neoplasms $(2,13,17)$. Soft tissues often show a woody consistency $(2,23)$, which can lead to a wrong diagnosis of malignancy $(2,24)$. Characteristic lesions develop slowly during weeks to months, giving a bluish or reddish appearance to the region. This presentation is often mistaken for cellulitis, although in fact representing venous congestion. Afterwards, a yellowish-serous exudate containing the characteristic sulfur granules drains onto the skin surface or oral mucosa (6). The infection can spread directly to the adjacent bones and muscles (25). 
Sulfur granules consist of colonies of Actinomyces that grossly resemble sulfur grains (13). They are yellowish macroscopic structures firm in consistency and visible to the naked eye (figure $2 \mathrm{e}$ ), varying from 100 to $1000 \mu \mathrm{m}$ in diameter. Sometimes they can be scarce or absent, requiring many microscopic sections of the sample collected through the fistula or abscess walls to be identified $(5,6)$. Although strongly suggestive of cervicofacial actinomycosis, sulfur granules are not pathognomonic, as they can be seen in other diseases such as nocardiosis and chromomycosis $(2,5,14,26)$.
Actinomyces shows filamentous or diptheroidal morphology, where the latter forms seem like non-pathogenic diphteroid Propionibacteria and the thin filaments exhibit V or Y ramifications and bacillary or coccoid forms (5). Colonies are visible by light microscopy with hematoxylin-eosin (H\&E) (7). Grocott-Gomori-methenamine $(5,7)$, methylene-blue, Gram or periodic acid-Schiff staining (PAS) (5), Methylene-blue, Gram, PAS and Grocott-Gomori staining disclose mycelial ramifications and Gram-positive filaments, which can be mistaken for streptococcus (5). With
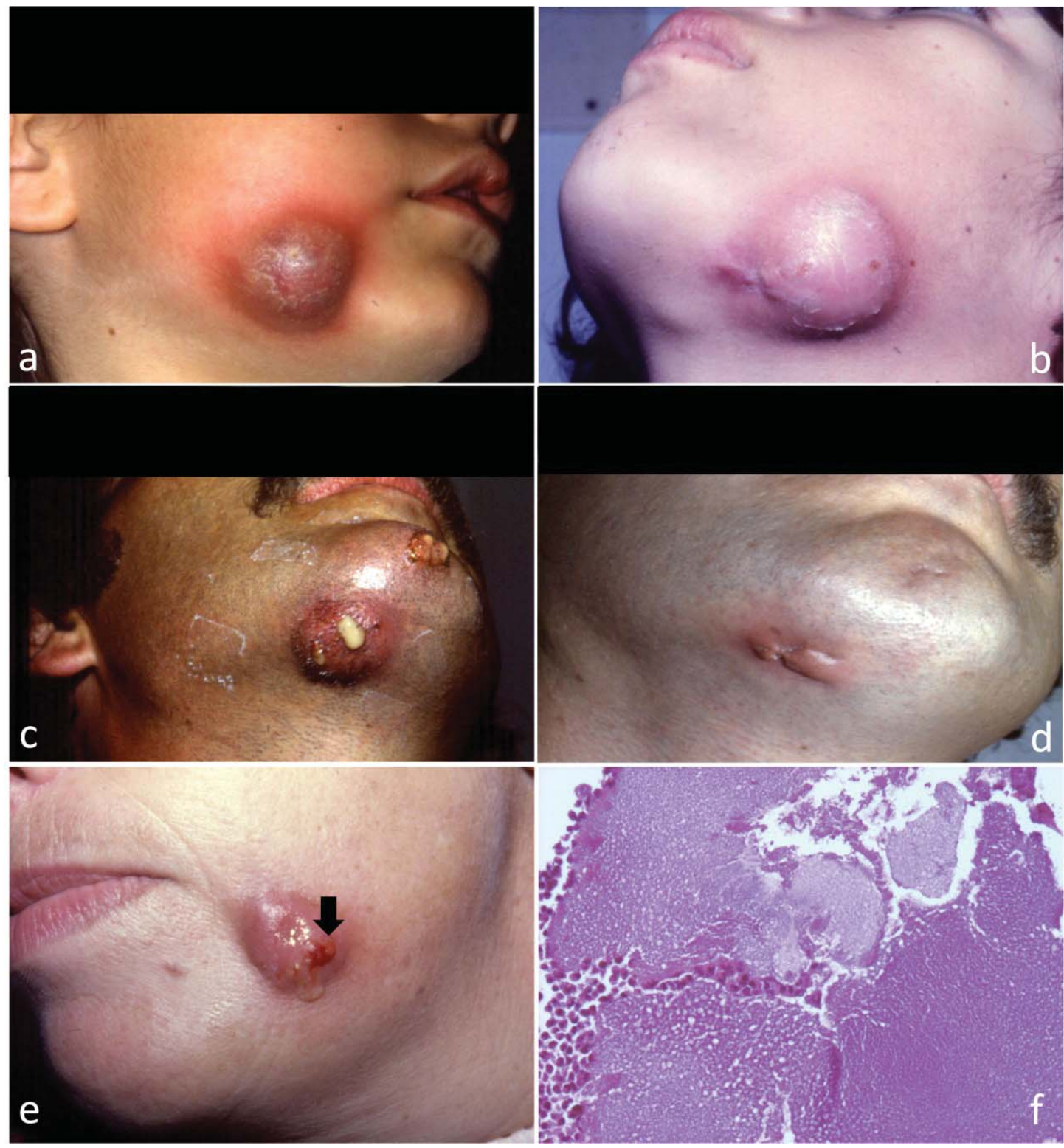

Figure 2. Cervicofacial actinomycosis. Solid mass in mandibular region in a child (a) and in an adult patient (b); the nodule becomes fistulated, with draining pus (c), which can lead to scarring after treatment (d); within the material discharged through the fistulae, it is possible to see the sulfur granules (e, arrow) corresponding to the Actinomyces colonies (f, HE, 400X). 
conventional methods such as Grocott-Gomori and $\mathrm{H} \& \mathrm{E}$, it is almost impossible to differentiate Actinomyces from Noccardia species (7). Even p-amino-salicylic acid, MacCallen-Goodpasture and Brown-Brenn do not offer any additional sensitivity (6).

The use of specific conjugated fluorescent antibodies allows rapid and highly specific identification of many species of Actinomyces through direct staining even in mixed infections or after formalin fixation $(2,5,7)$. The identification of individual filaments within granulation tissue is an advantage of this technique (7), even though confirmation by means of culture is necessary $(2,5)$.

$H \& E$ microscopic examination of an excised mass or tissue biopsy can reveal acute or chronic inflammation with loculation of neutrophils, lymphocytes, plasma cells and macrophages as well as dense fibrous connective tissue. Microcolonies are seen as crowded basophilic masses at the center and eosinophilic at periphery with radiating filamentous arms $(15,27)$, featuring the Splendore Hoeppli phenomenon (28). The number of plasma cells increases with lesion chronicity. Fibrosis can be mild in early infections, whereas chronic cases are associated with intense avascular fibrosis, which impairs even more the identification of Actinomyces colonies $(5,6)$.

\section{Treatment}

Cervicofacial actinomycosis treatment requires attention in identifying other pathogens, since the infection tends to be polymicrobial. It is also worth recalling that actinomycosis has a great potential for recurrence and, consequently, may require prolonged treatment (13). Actinomycetes are sensitive to beta-lactams (penicillin G IV), being these agents the first treatment choice (17). The efficacy of the therapy can be related not only to its direct effect on Actinomyces israelli, but also to antimicrobial suppression of the other organisms that are involved in the metabolic ecosystem enabling Actinomyces to flourish. These microorganisms include Actinobacillus actinomycetemcomitans, Bacteroides, Eikenella, and Fusobacterium (5).

Penicillin therapy should be intensive, and treatment duration depends on the severity of the case, sometimes lasting as long as 12 months. That is because of the avascular fibrotic walls of the lesions $(19,29,30)$, which maintains the anaerobic environment, stimulating the organisms' growth $(11,31)$. Depending on disease severity, therapy may consist of high doses of penicillin G IV (10 to 20 million IU/day) for days or weeks, followed by oral penicillin V (2 to $4 \mathrm{~g}$ / day) for 3 to 12 months $(13,17,32-34)$.

Actinomyces are in general sensitive to several antibiotics, where penicillin $\mathrm{G}$ is the first choice. In case of allergy to it, tetracycline, erythromycin, clindamycin or third-generation cephalosporins can be used $(3,14,35,36)$. It is important to point out that metronidazol, aminoglycosides, aztreonam, sulfamethoxazole-trimethoprim, penicillinase-resistant penicillins such as nafcillin and oxacillin, and cephalexin as well are not active against Actinomyces $(5,17)$.

Surgical intervention may be needed if the response to antibiotic therapy is insufficient $(2,13)$, or if there is an extensive area of necrotic tissue or large fistulas (2). It is sometimes indicated for bone curettage, necrotic tissue resection and drainage of extraoral fistulas. When cervicofacial infection is confined, with low intensity and not associated with drainage fistulas, a clinical approach is preferred instead of surgical interventions $(2,14)$. Table 1 summarizes reports in the literature about therapeutic management of cervicofacial actinomycosis. 
Table 1 - Therapeutic management of cervicofacial actinomycosis

\begin{tabular}{|c|c|c|c|c|c|}
\hline $\begin{array}{l}\text { Anatomic site of the } \\
\text { lesion (number of cases) }\end{array}$ & Drug and dosage & $\begin{array}{c}\text { Duration of } \\
\text { treatment } \\
\text { (months) }\end{array}$ & $\begin{array}{l}\text { Adjuvant } \\
\text { treatment }\end{array}$ & Outcome & Reference \\
\hline $\begin{array}{l}\text { Between pharynx and } \\
\text { epiglottis }(n=1)\end{array}$ & Amoxicillin 500 mg 8/8h & 3 & None & Remission & Volpi et al. (3) \\
\hline Parotid (n=1) & Prolonged course of penicillin (W/S) & $\mathrm{W} / \mathrm{S}$ & $\begin{array}{l}\text { Partial paroti- } \\
\text { dectomy }\end{array}$ & Remission & $\begin{array}{r}\text { Stewart et al. } \\
\text { (13) }\end{array}$ \\
\hline Submandibular $(\mathrm{n}=1)$ & High doses of penicillin (W/S) & $\mathrm{W} / \mathrm{S}$ & None & Remission & \\
\hline Parotid $(n=1)$ & $\begin{array}{l}\text { Amoxicillin/clavulanate } 2000 \mathrm{mg}+ \\
200 \mathrm{mg} \text { IV } 2 \mathrm{x} / \text { day(5 days); amoxi- } \\
\text { cillin+ clavulanate } 875 \mathrm{mg}+125 \mathrm{mg} \\
3 \mathrm{x} / \text { day (1 month) }\end{array}$ & 1.16 & $\begin{array}{l}\text { Partial paroti- } \\
\text { dectomy }\end{array}$ & Remission & $\begin{array}{l}\text { Lancella et al. } \\
\qquad(14)\end{array}$ \\
\hline Cervicolateral $(n=1)$ & $\begin{array}{l}\text { Piperacillinum/tazobactanum } 2 \mathrm{~g}+ \\
0.250 \mathrm{~g} 3 \mathrm{x} / \text { day (IV) and betameth- } \\
\text { asone IV, } 4 \mathrm{mg} / 2 \mathrm{ml} / \text { day( } 6 \text { days); } \\
\text { amoxicillin/clavulanate } 875 \mathrm{mg}+ \\
125 \mathrm{mg} \mathrm{3x/day} \mathrm{(1} \mathrm{month)}\end{array}$ & 1.2 & $\begin{array}{l}\text { Selective neck } \\
\text { dissection } \\
\text { (right side) }\end{array}$ & Remission & $\begin{array}{l}\text { Lancella et al. } \\
\qquad(14)\end{array}$ \\
\hline Mandibular $(n=1)$ & $\begin{array}{l}\text { Amoxicillin/clavulanate } 875 \mathrm{mg} \\
12 / 12 \mathrm{~h}\end{array}$ & 12 & None & Remission & Smith et al. (17) \\
\hline $\begin{array}{l}\text { Parotid (preauricular) } \\
(\mathrm{n}=1)\end{array}$ & $\begin{array}{l}\text { Ampicillin IV-sulbactam (4 days); } \\
\text { amoxicillin/clavulanate ( } 5 \text { days) }\end{array}$ & 0.3 & $\begin{array}{l}\text { Surgical drain- } \\
\text { age }\end{array}$ & Remission & $\begin{array}{r}\text { Sudhakar et al. } \\
\text { (23) }\end{array}$ \\
\hline $\begin{array}{l}\text { Mandibular }(n=6) \text {; cheek } \\
(n=2) ; \text { buccal }(n=2) \text {; infra- } \\
\text { temporal }(n=1) ; \text { infraor- } \\
\text { bital }(n=1) ; \text { sublingual } \\
(n=1) ; W / S(n=6)\end{array}$ & $\begin{array}{l}\text { Penicillin G IV } 12 \text { million IU /day } \\
\text { + metronidazole IV (1-16 days), } \\
\text { followed by oral AB or ceftriaxon } \\
2000 \mathrm{mg} / \text { day + clindamycin } 600 \mathrm{mg} \\
3 \mathrm{x} / \text { day }\end{array}$ & $0.2-4.5$ & $\begin{array}{c}\text { Incision }+ \\
\text { drainage and } \\
\text { debridement if } \\
\text { needed }(n=16) ; \\
\text { None }(n=3)\end{array}$ & Remission & $\begin{array}{r}\text { Moghimi et al. } \\
\text { (26) }\end{array}$ \\
\hline Parotid $(n=1)$ & $\begin{array}{l}\text { Crystalline penicillin, } 2 \text { million IU, } \\
\text { IV } 3 / 3 \mathrm{~h} \text { ( } 1 \text { month); trimethoprim } \\
160 \mathrm{mg} / \text { sulfamethoxazole } 800 \mathrm{mg} \\
\text { ( } 6 \text { months) }\end{array}$ & 7 & None & Remission & Dubey et al. (36) \\
\hline Parotid $(n=4)$ & $\begin{array}{l}\text { Penicillin G sodium IV } 12 \text { million } \\
\text { IU/day ( } 1.5 \text { months); penicillin V } \\
\text { oral } 1000 \mathrm{mg} / \text { day ( } 4.5 \text { months) }\end{array}$ & 6 & None & Remission & Sittitrai et al. (37) \\
\hline Submandibular $(\mathrm{n}=1)$ & High doses of penicillin (W/S) & 1 & $\begin{array}{l}\text { Surgical exci- } \\
\quad \text { sion }\end{array}$ & Remission & $\begin{array}{r}\text { Volante et al. } \\
\text { (38) }\end{array}$ \\
\hline
\end{tabular}

$\mathrm{W} / \mathrm{S}=$ without other specification; $\mathrm{AB}=$ antibiotic therapy 


\section{DISCUSSION}

Actinomyces israelli is a commensal of the normal oral microbiota, which can become pathogenic if oral mucosal integrity is compromised. It is not possible to anticipate the infection, therefore the decision of prescribing antibiotics before tooth extraction, for example, should not be based on the possibility of the patient developing actinomycosis, which is rather unlikely (5). Nevertheless, cases of patients showing late infections after dental treatment as well as recurrent infections after short-course antibiotic therapy should be a warning to the dentist about the possibility of the occurrence of cervicofacial actinomycosis $(5,37)$. Adequate oral hygiene with proper dental plaque control can prevent the disease, since it impairs the growth of Actinomyces in the oral environment (7).

Besides the possibility of actinomycosis mimicking neoplasms, the reverse process is also possible. That is, there are cases reported in the literature of squamous cell carcinomas misdiagnosed as being actinomycosis $(40,41)$. This is a serious concern, since the late diagnosis of this neoplasm drastically impairs its prognosis (40).

Although cervicofacial actinomycosis shows low prevalence, it involves significant morbidity and prolonged treatment. In this context, prevention is the best approach, where basic prophylactic procedures and oral hygiene are capable of preventing the disease (37). On the other hand, in the case of actinomycosis occurrence, it is important to establish a correct and early diagnosis (17), which demands knowledge about its etiopathogenesis and clinical characteristics. In conclusion, cervicofacial actinomycosis is a rare bacterial infection that evolves slowly and often mimics other clinical conditions such as malignancies. The diagnosis is based on clinical features including the sulfur granules, as well as identification of organisms in the examined tissue and positive cultures. Treatment consists in antibiotic therapy and can last up to 12 months in severe cases. Health care professionals' knowledge about the disease is crucial in a way to promote its prevention, early diagnosis and proper treatment.

Acknowledgments: We thank Dr. A. Leyva for English editing of the manuscript.

Conflict of interest: The authors declare there is no conflict of interest related to this work.

Financial Disclosure: The authors declare this study has received no financial support or funding

\section{REFERENCES}

1. Göçmen G, Varol A, Göker K, Basa S. Actinomycosis: report of a case with a persistent extraoral sinus tract. Oral Surg Oral Med Oral Pathol Oral Radiol Endod. 2011; 112(6): e121-123.

2. Wong VK, Turmezei TD, Weston VC. Actinomycosis. BMJ. 2011; 11;343:d6099.

3. Volpi L, Ferreli F, Bignami M, et al. A rare localization of actinomycosis mimicking ulcerative malignancy. Case Rep Otolaryngol. 2013;2013:323210.

4. Al-Hezaimi K. Apical actinomycosis: case report. J Can Dent Assoc. 2010; 76: a113.

5. Goldberg MH. Diagnosis and treatment of cervicofacial actinomycosis. Oral Maxillofac Surg Clin North Am. 2003; 15(1): 51-58.

6. Sharkawy AA. Cervicofacial actinomycosis and mandibular osteomyelitis. Infect Dis Clin North Am. 2007; 21(2): 543-556.

7. Walther K, Bruder E, Goldenberger D, Mayr J, Schaad UB, Ritz N. Actinomyces neuii Isolated From a 20-Month-Old Girl With Cervical Lymphadenitis. J Pediatric Infect Dis Soc. 2015; 4(3):e32-37.

8. Gajdács M, Urbán E, Terhes G. Microbiological and Clinical Aspects of Cervicofacial Actinomyces Infections: An Overview. Dent J. 2019;1;7(3): E85.

9. Könönen E, Wade WG. Actinomyces and related organisms in human infections. Clin Microbiol Rev. 2015;28(2):419-442.

10. Weese WC, Smith IM. A study of 57 cases of actinomycosis over a 36-year period. A diagnostic 'failure' with good prognosis after treatment. Arch Intern Med. 1975; 135(12):1562-1568.

11. Pulverer G, Schütt-Gerowitt H, Schaal KP. Human cervicofacial actinomycoses: microbiological data for 1997 cases. Clin Infect Dis. 2003; 15;37(4):490-497.

12. Lubomski M, Dalgliesh J, Lee K, Damodaran O, McKew G, Reddel S. Actinomyces cavernous sinus infection: a case and systematic literature review. Pract Neurol. 2018;18(5):373-377.

13. Stewart AE, Palma JR, Amsberry JK. Cervicofacial actinomycosis. Otolaryngol Head Neck Surg. 2005; 132(6): 957-959.

14. Lancella A, Abbate G, Foscolo AM, Dosdegani R. Two unusual presentations of cervicofacial actinomycosis and review of the literature. Acta Otorhinolaryngol Ital. 2008; 28(2): 89-93.

15. Carinci F, Polito J, Pastore A. Pharyngeal actinomycosis: a case report. Gerodondology. 2007; 24: $121-123$. 
16. Foster SV, Demmler GJ, Hawkins EP, Tillman JP. Pediatric cervicofacial actinomycosis. South Med J. 1993; 86(10): 1147- 1150.

17. Smith MH, Harms PW, Newton DW, Lebar B, Edwards SP, Aronoff DM. Mandibular actinomyces osteomyelitis complicating florid cemento- osseous dysplasia: case report. BMC Oral Health. 2011; 11: 21.

18. Harvey JC, Cantrell JR, Fisher AM. Actinomycosis: its recognition and treatment. Ann Intern Med. 1957; 46:868-885

19. Daamen N, Johnson JT. Nasopharyngeal actinomycosis: a rare cause of nasal airway obstruction. Laryngoscope. 2004; 114(8): 1403-1405.

20. Figueiredo LM, Trindade SC, Sarmento VA, de Oliveira TF, Muniz WR, Valente RO. Actinomycotic osteomyelitis of the mandible: an unusual case. Oral Maxillofac Surg. 2013; 17(4):299-302.

21. Oostman O, Smego RA. Cervicofacial actinomycosis: diagnosis and management. Curr Infect Dis Rep. 2005; 7(3): 170-174

22. Lad SD, Chandy MJ. Cranio-facial actinomycosis. Br J Neurosurg. 1991; 5: $361-370$.

23. Sudhakar SS, Ross JJ. Short-term treatment of actinomycosis: two cases and a review. Clin Infect Dis. 2004; 38(3): 444-447.

24. Park JK, Lee HK, Ha HK, Choi HY, Choi CG. Cervicofacial actinomycosis: $\mathrm{CT}$ and MR imaging findings in seven patients. Am J Neuroradiol. 2003; 24(3): 331-335.

25. Lewis MA. A cervicofacial infection due to Veillonella parvula in a patient with myxoedema Br Dent J. 1989; 166(12):437.

26. Moghimi M, Salentijn E, Debets-Ossenkop Y, Karagozoglu KH, Forouzanfar T. Treatment of Cervicofacial Actinomycosis: a report of 19 cases and review of literature. Med Oral Patol Oral Cir Bucal. 2013; 18(4):627-632.

27. Kullar PJ, Yates P. Actinomycosis of the middle ear. J Laryngol Otol. 2013; 127(7): 712-715.

28. Pritt B, Mount SL, Cooper K, Blaszyk H. Pseudoactinomycotic radiate granules of the gynaecological tract: review of a diagnostic pitfall. J Clin Pathol. 2006; 59(1):17-20.

29. Mullins JE Jr, Ogle O, Cottrell DA. Painless mass in the parotid region. J Oral Maxillofac Surg. 2000; 58(3):316-319.

30. Barabás J, Suba Z, Szabó G, Németh Z, Bogdán S, Huszár T. False diagnosis caused by Warthin tumor of the parotid gland combined with actinomycosis. J Craniofac Surg. 2003; 14(1): 46-50.

31. Cohn JE, Lentner M, Li H, Nagorsky M. Unilateral Maxillary Sinus Actinomycosis with a closed oroantral fistula. Case Rep. 2017;2017:7568390.

32. Moniruddin ABM, Begum H, Nahar K. Actinomycosis: an update. Medicine today. 2010; 22(1), 43-47.

33. Elzein F, Kharraz R, Arab N, Alotaibi F, Almohaya A,
Almutairy A. A case series of actinomycosis from a single tertiary care center in Saudi Arabia. IDCases. 2019; 15: e00521.

34. Brook I. Actinomycosis: diagnosis and management. South Med J. 2008; 101(10): 1019-1023.

35. Valour F, Sénéchal A, Dupieux C, et al. Actinomycosis: etiology, clinical features, diagnosis, treatment, and management. Infect Drug Resist. 2014; 5;7:183-197.

36. Mark H. Antimicrobial Therapy. In: Gilbert DN, Moellering RC Jr, Sande MA. The Sanford Guide to Antimicrobial Therapy. 31st ed. Sperryville, VA: Antimicrobial Therapy Inc; 2010.

37. Dubey A, Murthy JG, Banerjee PK. Actinomycosis of the parotid gland. Indian J Otolaryngol Head Neck Surg. 2004;56(4): 306-308.

38. Sittitrai P, Srivanitchapoom C, Pattarasakulchai T, Lekawanavijit S. Actinomycosis presenting as a parotid tumor. Auris Nasus Larynx. 2012; 39(2): 241243.

39. Volante M, Contucci AM, Fantoni M, Ricci R, Galli J. Cervicofacial actinomycosis: still a difficult differential diagnosis. Acta Otorhinolaryngol Ital. 2005; 25(2): 116-119.

40. Raj AT, Patil S. Cervicofacial actinomycosis can obscure a malignancy: A case report. Oral Oncol. 2018;80:94

41. Mokni S, Zeriaa S, Belajouza C, Denguezli M, Nouira R. Oral squamous cell carcinoma of the mandibular region mimicking cervico-facial actinomycosis. Presse Med. 2018; S0755-4982(18): 30194-5.

Recibido: 06-01-20

Aceptado: 13-05-20 